\title{
Influence of tree species on richness and diversity of epigeous fungal communities in a French temperate forest stand
}

\author{
Marc BUÉE ${ }^{a, *}$, Jean-Paul MAURICE ${ }^{b}$, Bernd ZELLER ${ }^{c}$, Sitraka ANDRIANARISOA ${ }^{c}$, \\ Jacques RANGER ${ }^{c}$, Régis COURTECUISSE ${ }^{d}$, Benoît MARÇAIS ${ }^{a}$, François LE TACON ${ }^{a}$ \\ aINRA Nancy, UMR INRA/UHP 1136 Interactions Arbres/Microorganismes, 54280 Champenoux, France \\ ${ }^{\mathrm{b}}$ Groupe Mycologique Vosgien, 18 bis, place des Cordeliers, 88300 Neufchâteau, France \\ 'INRA Nancy, UR 1138 Biogéochimie des Ecosystèmes Forestiers, 54280 Champenoux, France \\ ${ }^{\mathrm{d}}$ Université de Lille, Faculté de Pharmacie, F59006 Lille, France
}

\section{A R T I C L E I N F O}

Article history:

Received 30 September 2009

Revision received 10 May 2010

Accepted 21 July 2010

Available online 6 October 2010

Corresponding editor: Anne Pringle

\section{Keywords:}

Conifer plantation

Conservation

Host specificity

Nitrogen mineralisation

Saprotrophic and ectomycorrhizal

(ECM) fungi

Species richness

Temperate forest

\begin{abstract}
A B S T R A C T
Epigeous saprotrophic and ectomycorrhizal (ECM) fungal sporocarps were assessed during $7 \mathrm{yr}$ in a French temperate experimental forest site with six 30-year-old mono-specific plantations (four coniferous and two hardwood plantations) and one 150-year-old native mixed deciduous forest. A total of 331 fungal species were identified. Half of the fungal species were ECM, but this proportion varied slightly by forest composition. The replacement of the native forest by mono-specific plantations, including native species such as beech and oak, considerably altered the diversity of epigeous ECM and saprotrophic fungi. Among the six mono-specific stands, fungal diversity was the highest in Nordmann fir and Norway spruce plantations and the lowest in Corsican pine and Douglas fir plantations. Several factors, connected to the mono-specificity of host trees, could be involved in regulating fungal diversity. Interestingly, this study showed a significant negative correlation between fungal species richness and nitrogen mineralisation, indicating that increases in mineral $\mathrm{N}$ availability are associated with decline in saprotrophic and ECM community richness. The frequency of occurrence of fruit bodies of 11 edible fungal species that naturally occur in the native forest was modified by the treatments.
\end{abstract}

(c) 2010 Elsevier Ltd and The British Mycological Society. All rights reserved.

\section{Introduction}

Fungal species can be divided into three categories that correspond to different strategies of carbon acquisition: mutualistic, saprotrophic and parasitic (Schmit \& Mueller 2007); however, the distinction between these three categories is not complete. Several ectomycorrhizal fungi are able to partially use dead organic matter (El-Badaoui \& Botton 1989; Durall et al. 1994), and some pathogenic fungi, such as Armillaria spp., show saprotrophic abilities. The trophic status of fungi strongly influences fundamental functions within the forest ecosystem, as illustrated by the interactions between saprotrophic and ectomycorrhizal fungi that directly drive carbon and nitrogen cycling (Lindahl et al. 2007). Numerous authors have shown that spatial and temporal variation in decomposer and ectomycorrhizal fungal communities are affected by biotic and abiotic factors, including seasonal cycles (Buée et al. 2005; Koide et al. 2007), micro-site heterogeneity (Tedersoo et al. 2003, 2008b; Genney et al. 2005; Buée et al. 2007), soil and organic matter quality (Peter et al. 2001;

\footnotetext{
* Corresponding author. Tel.: +33 (0) 383394072 .

E-mail address: buee@nancy.inra.fr (M. Buée).

1754-5048/\$ - see front matter ๔ 2010 Elsevier Ltd and The British Mycological Society. All rights reserved. doi:10.1016/j.funeco.2010.07.003
} 
Nordén et al. 2004), stand age (Nordén \& Paltto 2001), host tree species (Molina \& Trappe 1982; Newton \& Haigh 1998; Ishida et al. 2007; Tedersoo et al. 2008a) and forest management (Erland \& Taylor 2002). The structure of fungal communities, and especially the balance between dominant and rare species, differs between forest ecosystems. The balance is influenced by the composition and structure of the upper layer of the forest formed by the tree crowns, through modifications of water and soil nutrient availability, quality of the litter, and microclimate conditions. Moreover, several studies showed that the relative proportions of fungal trophic groups in forest ecosystems are correlated with environmental parameters such as altitude, temperature or rainfall (Laganà et al. 1999; Richard et al. 2004).

Diversity of tree species also influences saprotrophic fungal communities. The type of tree debris, such as needles, dead leaves or cones, strongly influences the presence or absence of specialised saprotrophic fungi (Takumasu et al. 1994; Zhou \& Hyde 2001). In a Swedish hemi-boreal forest, Lindhe et al. (2004) showed that, among saprotrophic fungi developing on logs or stumps, all but two species on deciduous hosts were found on more than one tree species, while almost half the number of species recorded from spruce (Picea abies) were found only on this host. They also showed, by using Sörenson's similarity indices, that the deciduous trees were more similar to each other than to spruce. The highest similarities were found between birch (Betula sp.) and aspen (Populus tremuloides), followed by birch-oak (Quercus) and aspen-oak. Investigating the fungal communities of 86 plots distributed in all Switzerland, Küffer \& Senn-Irlet (2005) showed that the diversity of host trees had a strong effect on the species richness of wood decaying fungi. There were more corticoid fungal species on deciduous wood than on coniferous wood. Beech (Fagus sylvatica) wood was particularly rich in saprotrophic fungi, while Norway spruce wood was less favourable to the diversity of wood decaying fungi.

The influence of the replacement of a native forest by mono-specific plantations on fungal diversity has been studied in several countries. Some data suggest that coniferous plantations can display significant fungal diversity (Newton \& Haigh 1998; Humphrey et al. 2000), but other studies showed that exotic conifer plantations display a lower fungal diversity than native hardwood stands (Ferris et al. 2000). In New Zealand, replacing Nothofagus forests with Pinus radiata reduced the diversity of indigenous ECM fungi (Amaranthus 1998). In Europe, replacement of native deciduous forests by P. abies or Pseudotsuga menziesii also reduced the diversity of ECM fungi (Jansen \& de Vries 1988).

The aim of this study was to experimentally determine how the richness and diversity of a natural fungal community could be affected by a substitution of forest tree species, which is a common forestry practice. Using an experiment that began $30 \mathrm{yr}$ ago in a very homogeneous stand, we assessed fungal diversity over $7 \mathrm{yr}$ in coniferous (Norway spruce, Nordmann fir (Abies nordmanniana), Douglas fir (P. menziesii), Corsican pine (Pinus nigra)) and deciduous (oak and beech) mono-specific plantations and compared the newformed fungal communities with the native deciduous forest (oak, beech, birch and hazel (Corylus avellana)) fungal communities.

\section{Material and methods}

\section{Site description}

The experimental site of Breuil-Chenue forest is situated in the Morvan Mountains, Burgundy, France (latitude $47^{\circ} 18^{\prime} 10^{\prime \prime}$, longitude $\left.4^{\circ} 4^{\prime} 44^{\prime \prime}\right)$. The elevation is $640 \mathrm{~m}$, the annual rainfall $1280 \mathrm{~mm}$, the mean annual potential evapotranspiration $640 \mathrm{~mm}$ and the mean annual temperature $9{ }^{\circ} \mathrm{C}$. The soil parent material is granite, containing $23.5 \%$ quartz, $44 \% \mathrm{~K}$ feldspar, $28.5 \%$ plagioclase, $1.6 \%$ biotite and $1.6 \%$ muscovite. The soil is an Alocrisol with a pH ranging between 4 and 4.5 and displaying micro-podzolisation features in the upper mineral horizon (Ranger et al. 2004). The humus is a dysmoder with three layers (L, F and H). The mean nitrogen deposition rate is $15 \mathrm{~kg} \mathrm{Nha}^{-1} \mathrm{yr}^{-1}$ (Ranger et al. 2004).

\section{Treatments}

The native forest was an old coppice with standards, a traditional European system of management where timber trees (standards) are grown above a coppice. The present mixed coppice results from a native forest system but one that has been intensively cultivated for centuries with strong effects on tree composition, density and age structure. Dominant trees were mainly beech ( $90 \%$ of the stems) and oak (Quercus sessiliflora). The coppice was composed of oak (Q. sessiliflora), birch (Betula verrucosa) and hazel. In 1975, a part of the native forest located on a homogeneous soil type was clear-cut. Timber trees were harvested, while stumps were mechanically extracted and left in piles with the cut coppice. In 1976, the clear-cut area was planted with the following species: beech, oak (Q. sessiliflora), Norway spruce, Douglas fir, Corsican pine (P. nigra ssp. laricio var. corsicana) and Nordmann fir. Current work focused on native plot with an area of $5000 \mathrm{~m}^{2}$, while each plantation plot had an area of $1000 \mathrm{~m}^{2}$ (Fig S1). For each coniferous plantation, two plots of $1000 \mathrm{~m}^{2}$ were added and fertilised as follows: in 1979, $37 \mathrm{~g}$ of $\mathrm{P}_{2} \mathrm{O}_{5}$, as triple superphosphate, $15 \mathrm{~g}$ of $\mathrm{K}_{2} \mathrm{O}$ as potassium sulphate and $3.4 \mathrm{~g}$ of $\mathrm{N}$ were applied to each plant; in 1983, $160 \mathrm{~kg}$ of $\mathrm{P}_{2} \mathrm{O}_{5}$ and $1120 \mathrm{~kg}$ of $\mathrm{CaO}$ were applied per hectare as crushed phosphatic limestone. In 2007, plantation trees were between $10 \mathrm{~m}$ and $20 \mathrm{~m}$ high, and their stem density ranged between 700 (coniferous trees) and 3200 (deciduous trees) trees per ha.

\section{Sporocarps inventories and sampling}

The fungal inventories started in Aug. 2001 and ended in Nov. 2007. Two or three times per year in autumn, mature fungal sporocarps of all macromycetes, exhibiting all the characters necessary for an unequivocal identification, were inventoried in the 11 treatments using a presence-absence assessment. To avoid too much difference between the area inventoried in the native stand and the planted sites, we used only one replicate for the native site (block 1 ) as discussed above. Thus, the total area inventoried per treatment was $5000 \mathrm{~m}^{2}$ for the native site, $4000 \mathrm{~m}^{2}$ for each of the four coniferous plantations $\left(2000 \mathrm{~m}^{2}\right.$ for the fertilised plots, $2000 \mathrm{~m}^{2}$ for the non-fertilised plots) and $2000 \mathrm{~m}^{2}$ for each of the two broad-leaved tree 
plantations. To compare the hardwood and coniferous plantations, we excluded the coniferous fertilised plots and the native stand. Consequently, the inventoried area was exactly the same in the six plantations.

There were a total of 19 assessments allowing a maximum of 209 presences for each fungal species (19 assessments $\times 11$ treatments $=209$ dates/sites). Traditional mycological methods were used for taxonomic determination (Courtecuisse \& Duhem 1995). Uncommon fungal species were identified by one of us (Maurice J.P.) who is specialised in fungal taxonomy and according to the new "French Reference of Mycology" (http:// www.mycofrance.org) coordinated by Courtecuisse (2008). The different species were classified into ecological groups according to the literature and their niches in the collecting site were recorded. ECM fungi (EMF) represented a free ecological group. The other fungi were divided into five groups: wood decaying fungi living on dead branches, stumps, trunks or living wood (WDF); wood decaying fungi living on small twigs on the ground (TSF); litter decaying fungi living on $\mathrm{F}$ and $\mathrm{H}$ layers (LDF); pathogenic fungi living on roots or trunks (PF); and other fungi (OF).

\section{Microclimatic measurements}

A rain gauge was placed on a tower above the planted site with the shortest trees (Nordmann fir), and daily measurements were recorded. A second gauge was placed in a clearing close to the experimental site. In the native site and in one of the planted plots, five rain gauges were randomly placed at $130 \mathrm{~cm}$ above ground level, and daily measurements were recorded during $4 \mathrm{yr}$.

Air temperature within a radiation shield $\left(\mathrm{T},{ }^{\circ} \mathrm{C}, 130 \mathrm{~cm}\right.$ above ground level) and soil temperature $\left(\mathrm{T},{ }^{\circ} \mathrm{C}, 10,20,60 \mathrm{~cm}\right.$ depth) were measured with a Pt $100 \Omega$ (Omega, Trappes, France). Meteorological variables were monitored every $1 / 4 \mathrm{hr}$ inside the stands.

Soil humidity (H \%, 10, 20, $60 \mathrm{~cm}$ depth) was measured from 8 Jan. 2003 to 19 Apr. 2004 with two TDR probes in four plantations: Douglas fir coupled with beech (one TDR probe for both treatments) and Norway spruce coupled with oak (another TDR probe for both treatments).

\section{Soils sampling and analysis}

In 2001, soils were collected in each treatment at five randomly selected sampling locations. L, F and $\mathrm{H}$ layers, $\mathrm{A}_{1}$ $(0-5 \mathrm{~cm})$ and $B$ horizons were collected separately. The five samples were pooled together per layer or horizon, sieved at $4 \mathrm{~mm}$ and oven dried at $65^{\circ} \mathrm{C}$. Soil $\mathrm{pH}$ was measured in deionised water (soil/water ratio 1/10 for organic layers and 1/ 15 for the other horizons) with a glass electrode. Total C and $\mathrm{N}$ were determined by dry combustion (Elemental analyser Carbo Erba NA, 1500) of an aliquot of ground soil. Cationic saturation and cationic exchange capacity were also measured. Available phosphorus was measured after a double extraction with $\mathrm{NaOH} \mathrm{M} / 10$ and $\mathrm{H}_{2} \mathrm{SO}_{4} \mathrm{M} / 250$ (Table S1).

\section{Net nitrogen mineralisation potential and nitrification potential}

The net nitrogen mineralisation potential and the nitrification potential were measured from 0 to $15 \mathrm{~cm}$ in five soil samples collected randomly across each treatment, except the fertilised ones. In 2007, the soil was sampled in each treatment and sieved (4 mm grid), roots were removed and the soil samples $(n=5)$ were transferred to the laboratory. Aliquots were oven dried at $105^{\circ} \mathrm{C}$ for $48 \mathrm{hr}$ to determine soil moisture. For each soil core, $20 \mathrm{~g}$ of sieved mineral soil were shaken in $1 \mathrm{M} \mathrm{KCl}$ $(100 \mathrm{ml})$ and then filtered. The nitrate $\left[\mathrm{NO}_{3}^{-}\right]$and ammonium $\left[\mathrm{NH}_{4}^{+}\right]$concentrations of extracts were measured using continuous flow colorimetry (TrAAcs 800, Bran \& Luebbe, Hamburg, Germany) and expressed as $\mathrm{mg} \mathrm{N} \mathrm{kg}^{-1}$ dry matter (d.m). Potential net $\mathrm{N}$ mineralisation (PNM) and potential net nitrification (PNN) were measured in mineral soil samples. Aliquots of mineral soil (200 g) at sampling moisture (close to field capacity) were put into jars with airtight lids and incubated at $20^{\circ} \mathrm{C}$ in the dark for $42 \mathrm{~d}$. Inorganic $\mathrm{N}\left(\mathrm{NH}_{4}^{+}\right.$and $\left.\mathrm{NO}_{3}^{-}\right)$ was extracted at the beginning and at the end of the incubation. Potential net $\mathrm{N}$ mineralisation was the amount of total inorganic $\mathrm{N}$ accumulated during the incubation period whereas the potential of nitrification was the amount of $\mathrm{NO}_{3}^{-}$ accumulated. Both were expressed as $\mathrm{mg} \mathrm{N} \mathrm{kg}^{-1}$ soil d (Andrianarisoa et al. 2009).

\section{Statistical analysis}

The comparison of the fungi community in the different treatments was done by correspondence analysis using the "corresp" procedure of SAS. Only presence or absence within each plot during at least one of the survey dates was taken into account. Species seen just one time (only one date in only one plot) were omitted from the analysis. They were, however, included as supplementary data.

For analysis of the impact of the treatments on fungal diversity, a multivariate variance analysis was done taking into account two factors, the host type plantation (coniferous versus deciduous trees) and the fertilisation treatment (fertilised versus non-fertilised). Repetitions for the fertilisation treatment were the different hosts. We did not use data from the native forest plot for this analysis as this plot has a much higher surface.

Two types of analysis on the presence of the individual fungal species were also done. To study the fertilisation effect we considered each coniferous plantation as a replicate $(n=4)$. Only fungal species found a minimum of three times in at least one plantation were considered. The analysis was a multivariate variance analysis taking into account two factors, the host species and the fertilisation treatment. Fungal species frequencies were transformed to the Arcsin or square root before analysis.

Second, we characterized the degree of fungal specificity towards one host. For that, we computed the relative probability (risk) of presence within the plantations of a particular host versus its presence in the plantations of the five other hosts as:

$R R_{x_{1}}=\left[\frac{\operatorname{Pr}_{x_{1}}}{N t_{x_{1}}}\right] /\left[\frac{\sum_{n=2}^{n=6} \operatorname{Pr}_{x_{n}}}{\sum_{n=2}^{n=6} N t_{x_{n}}}\right]$

with $\mathrm{Pr}_{\mathrm{x}_{1}}$, the number of observed presence of the fungal species in the host plantation; $\mathrm{Nt}_{\mathrm{x}_{1}}$, the total number of observations for that host plantations; $\operatorname{Pr}_{x_{n}}$, the number of 
observed presence of the fungal species in the five other host plantations; and $\mathrm{Nt}_{x_{n}}$, the total number of observations for the five other host plantations. For that analysis, data from the native forest were excluded, and data from fertilised and unfertilised plots of the individual conifer species were pooled. All analyses were done using the SAS software (SAS/STAT 8.1, SAS Institute Inc., Cary, NC).

\section{Results}

\section{Inclusive effect of the treatments}

In the whole experiment, we recorded a total of 115 fungal genera and 331 species (Table S2, Supplementary data). In the native stand, 186 species were recorded, and the cumulative number grew almost linearly from 2001 to 2007 . The number of fungal species was lower in all of the planted sites than in the native site, and varied from 59 to 124 (Fig 1; Table 1). Nevertheless, as in the native site, the cumulative number of fungal species in the plantations continued to increase with time.

The native forest had a higher diversity of fungal species than the mono-specific plantations. The value of the Shannon-Wiener index was 4.84 in the native site, while in the plantations it varied from 3.79 to 4.44 (Table 1). Variance analysis showed that within planted plots, the Shannon index was not affected by fertilisation $(F=0.07 ; P=0.798)$ and did not differ between coniferous and broad-leaved plots $(F=0.12$; $P=0.738$; Table 1).

Overall, the percentage of ECM fungi was a little higher than the percentage of saprotrophic fungi (53\% versus $47 \%$ ), but it varied from $40.7 \%$ to $63.3 \%$ depending on the treatment (Table 1).

The three dominant saprotrophic groups were the wood decaying fungi (WDF) living on dead branches, stumps or trunks, the litter decaying fungi (LDF), and the wood decaying fungi living on small twigs (TSF), representing $20 \%, 12 \%$ and $8 \%$ of the total species count, respectively (Fig S2). All of the other groups were minor by comparison and represented a total of $7 \%$ of the total species count (details in Table S2).

The treatments differed according to axes 1 and 2 of the correspondence analysis (Fig 2). Axis 1, which represents $21 \%$ of the total variability, adequately differentiated the fungal species of the deciduous stands from those of coniferous plantations. This structure reflects the relevance of several factors such as the host specificity of ectomycorrhizal fungi, the quality of the litter for saprotrophic fungi, the age or the stage of stand development and the number of hosts. Axis 2, representing $13 \%$ of the total variability, differentiated the four treatments showing higher fungal diversity (native forest, beech, Nordmann fir and Norway spruce) from treatments displaying a weaker fungal diversity (oak, Douglas fir and Corsican pine).

According to the correspondence analysis, soil fertilisation did not affect the fungal communities. Indeed, fertilised/ unfertilised plots of the same conifer tree were very close (Fig 2). When the impact of fertilisation was assessed on individual fungal species, the only species that were significantly affected by this treatment were Mycena epipterygia, Clitocybe vibecina and Laccaria bicolor, which were negatively affected (respectively $F=15.6, \quad P=0.029 ; \quad F=15.78, \quad P=0.029$ and $F=74.72, P=0.003)$.

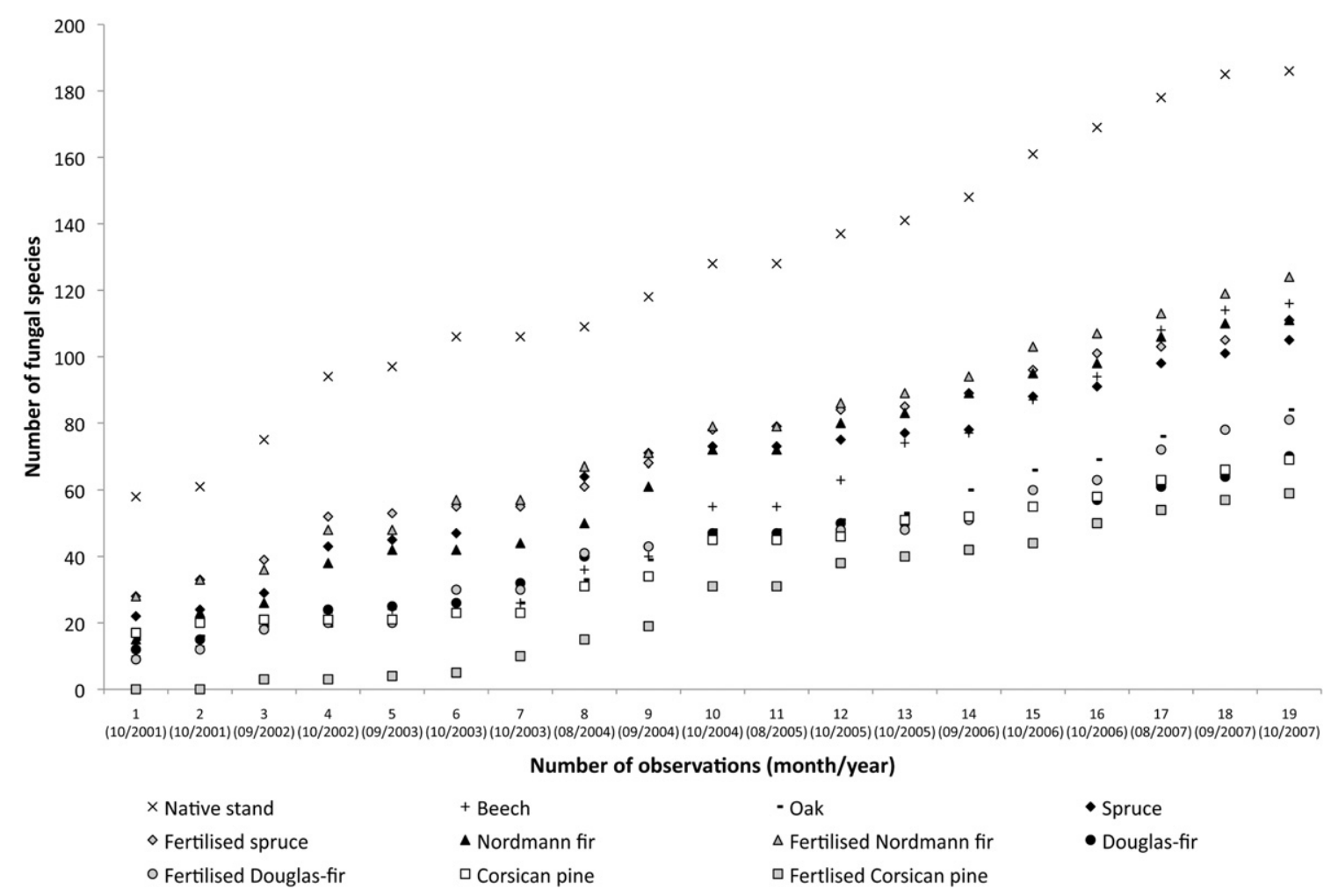

Fig 1 - Cumulative numbers of fungal species by treatment and number of assessments from 2001 to 2007. 
Table 1 - Fungal diversity (total number of fungi and Shannon-Wiener index) and percentage of ECM and non-mycorrhizal fungi according to the different treatments

\begin{tabular}{|c|c|c|c|c|c|}
\hline Treatments & Fertilisation & $\begin{array}{l}\text { Number of fungal } \\
\text { species }\end{array}$ & $\begin{array}{l}\text { Shannon-Wiener } \\
\text { index }\left(\mathrm{H}^{\prime}\right)\end{array}$ & $\begin{array}{c}\text { Percentage of } \\
\text { ectomycorrhizal fungi }\end{array}$ & $\begin{array}{c}\text { Percentage of } \\
\text { non-mycorrhizal fungi }\end{array}$ \\
\hline Native forest & - & 186 & 4.89 & 56.45 & 43.55 \\
\hline Beech & - & 116 & 4.36 & 61.21 & 38.79 \\
\hline Oak & - & 84 & 4.04 & 51.19 & 48.81 \\
\hline Nordmann fir & - & 109 & 4.34 & 63.30 & 36.70 \\
\hline Nordmann fir & + & 124 & 4.44 & 54.84 & 45.16 \\
\hline Norway spruce & - & 105 & 4.30 & 46.67 & 53.33 \\
\hline Norway spruce & + & 111 & 4.37 & 52.25 & 47.75 \\
\hline Douglas-fir & - & 70 & 3.90 & 45.71 & 54.29 \\
\hline Douglas-fir & + & 81 & 4.07 & 50.62 & 49.38 \\
\hline Corsican pine & - & 69 & 3.89 & 49.28 & 50.72 \\
\hline Corsican pine & + & 59 & 3.79 & 40.68 & 59.32 \\
\hline
\end{tabular}

Effects of the treatments through modifications of microclimatic conditions and soil fertility

In Douglas fir, Nordmann fir and Norway spruce plantations, the rainfall interception in autumn was between $44 \%$ and $50 \%$, while it was only about $30 \%$ in the angiosperm tree and Corsican pine treatments, and $34 \%$ in the native stand (Table S3). Similarly, the humidity of the upper part of the soil was always higher in the deciduous tree treatments than in the coniferous treatments (Table S4).

Nitrogen mineralisation was the only soil variable significantly $(P \leq 0.05)$ related to fungal species richness. There was a negative correlation between nitrification potential and the number of fungal species recorded (Fig 3). The native stand and two coniferous plantations (Norway spruce and Nordmann fir) exhibited low nitrification potential and high fungal species richness. Conversely, the two deciduous tree plantations and two coniferous plantations (Douglas fir and Corsican

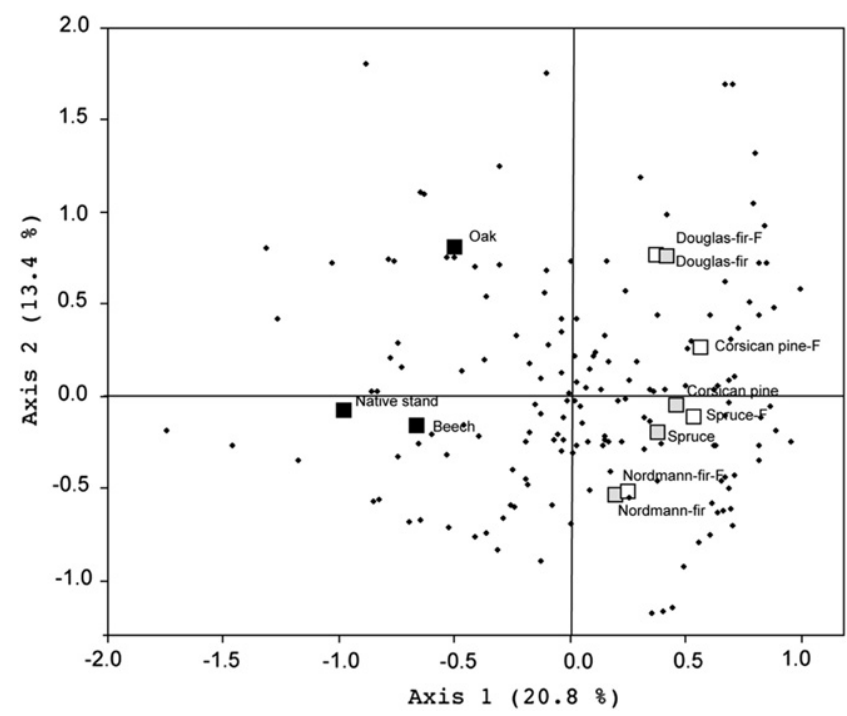

Fig 2 - Correspondence analysis (COA). Representation according to axis 1 and 2, showing the effects of treatments on fungal community composition. Fungal species; Deciduous treatments; $\square$ Non-fertilised coniferous treatments; $\square$ Fertilised coniferous treatments. pine) exhibited high nitrification potential and low fungal species richness.

\section{Host preference}

Of the 331 fungal species recorded, $31 \%$ were present only under coniferous trees, $29 \%$ were present only under deciduous trees and $40 \%$ were more or less ubiquitous and common to the deciduous and coniferous trees (Table S2). In contrast to the widely distributed species, numerous other ectomycorrhizal or saprotrophic fungi exhibited a narrower host preference (Table 2). We retained only the species observed on at least four survey dates and with a relative chance of presence in a plantation type versus other plantation types of more than five (see Statistical analysis). The preferential association was statistically significant for all fungi species shown in Table 2. A total of 107 fungal species (ECM and saprotrophs) were associated with only one forest tree species, 62 with two tree species, 50 with three and about 20 with four, five or six tree species (Fig 4).

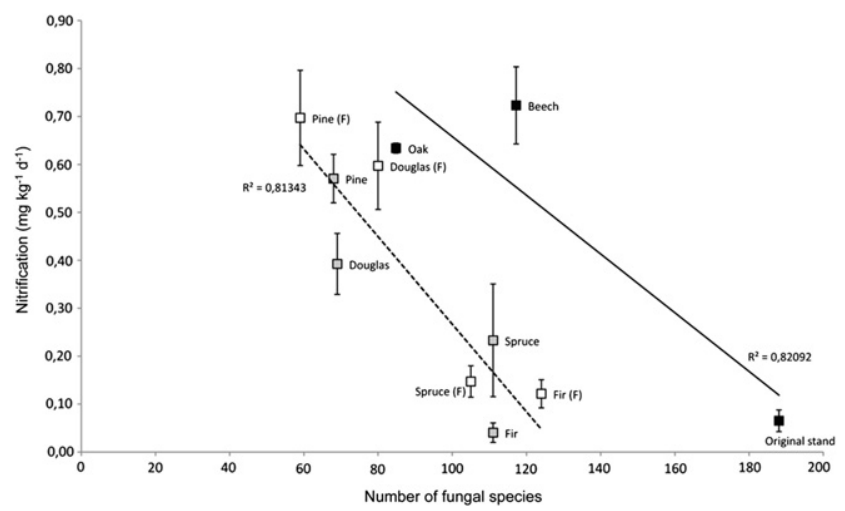

Fig 3 - Correlation between fungal richness and nitrification potential in the 11 treatments of the Breuil site. Deciduous treatments; $\square$ Non-fertilised coniferous treatments; $\square$ Fertilised coniferous treatments. Solid line: predicted line fit to the deciduous data (with $r^{2}$ correlation coefficient). Dotted line: predicted line fit to the coniferous data (with $r^{2}$ correlation coefficient). Bars $=$ Standard Error of the mean $(n=5)$. 
Table 2 - Host preference of saprotrophic and ectomycorrhizal fungi: relative chance of presence in the putative host tree plantation of fungal species compared to other tree species plantations

\begin{tabular}{|c|c|c|c|c|c|c|c|c|}
\hline Genus & Species & $\begin{array}{c}\text { Ecological } \\
\text { groups }\end{array}$ & Beech & Oak & Douglas-fir & $\begin{array}{c}\text { Norway } \\
\text { Spruce }\end{array}$ & $\begin{array}{l}\text { Corsican } \\
\text { pine }\end{array}$ & Nordmann fir \\
\hline Amanita & muscaria & EMF & & & & 6.5 & & \\
\hline Amanita & porphyria & EMF & & & & 15.3 & & \\
\hline Baeospora & myosura & OF & & & & 15.3 & & \\
\hline Bjerkandera & adusta & DWSF & 35.6 & & & & & \\
\hline Boletus & aestivalis & EMF & & & & 8.7 & & \\
\hline Cantharellus & cibarius & EMF & 62.3 & & & & & \\
\hline Cantharellus & tubaeformis & EMF & & & & 16.4 & & \\
\hline Chalciporus & piperatus & EMF & & & & 36.0 & & \\
\hline Clauulina & rugosa & EMF & & & & & & 10.2 \\
\hline Clitocybe & cerussata & LDF & & & & & & \\
\hline Cortinarius & cinnamomeus & EMF & & & & & & 15.0 \\
\hline Cortinarius & delibutus & EMF & 35.6 & & & & & \\
\hline Cortinarius & obtusus & EMF & & & & & & 7.3 \\
\hline Cortinarius & semisanguineus & EMF & & & & & & 69.4 \\
\hline Crepidotus & cesatii & TSF & 13.3 & 5.9 & & & & \\
\hline Cystoderma & jasonis & TSF & & & & & & 7.0 \\
\hline Cystoderma & lilacipes & WDF & & & & & & 10.2 \\
\hline Entoloma & conferendum & LDF & & & & & & 8.2 \\
\hline Gomphidius & glutinosus & EMF & & & & 19.6 & & \\
\hline Hebeloma & bulbiferum & EMF & & & 7.1 & & & \\
\hline Hydnum & rufescens & EMF & & & 8.2 & & & \\
\hline Lactarius & hepaticus & EMF & & & & & 12.2 & \\
\hline Lactarius & quietus & EMF & & 116 & & & & \\
\hline Lactarius & rufus & EMF & & & & & & 9.2 \\
\hline Lactarius & turpis & EMF & & & & & & 10.2 \\
\hline Lepista & inversa & LDF & & & & & & 36.7 \\
\hline Marasmiellus & perforans & $\mathrm{OF}$ & & & & 5.2 & & \\
\hline Mycena & inclinata & $\mathrm{OF}$ & 8.9 & & & & & \\
\hline Mycena & stylobates & LDF & & & 6.8 & & & \\
\hline Phaeocollybia & lugubris & OF & & & & & & 12.2 \\
\hline Pholiota & lenta & LDF & 4.4 & 11.1 & & & & \\
\hline Postia & caesia & WDF & & & & 5.2 & & \\
\hline Postia & ptychogaster & WDF & & & & 39.3 & & \\
\hline Postia & stiptica & WDF & & & & 29.5 & & \\
\hline Russula & atropurpurea & EMF & & & & & & 26.5 \\
\hline Russula & brunneoviolacea & EMF & 17.8 & & & & & \\
\hline Russula & cyanoxantha & EMF & 16.0 & 3.6 & & & & \\
\hline Russula & fragilis & EMF & & & & & & 9.0 \\
\hline Scleroderma & citrinum & EMF & & 5.6 & & & & \\
\hline Stereum & hirsutum & WDF & 16.0 & & & & & \\
\hline Tramates & versicolor & WDF & 10.7 & & & & & \\
\hline Tricholoma & fulvum & EMF & & & & & & 73.5 \\
\hline Tricholoma & ustale & EMF & 97.8 & & & & & \\
\hline Tricholomopsis & rutilans & WDF & & & 6.8 & & & \\
\hline Xerula & radicata & OF & 8.9 & & & & & \\
\hline Xylaria & hypoxylon & WDF & 14.2 & & & & & \\
\hline
\end{tabular}

Native forest is excluded from the analysis while fertilised plots are included. EMF, ectomycorrhizal fungi; WDF, wood decaying fungi; LDF, litter decaying fungi living on F and $\mathrm{H}$ layers; TSF, wood decaying fungi living on small twigs on the ground; OF, other fungi.

Among the ectomycorrhizal fungi, seven, Amanita rubescens, Laccaria amethystina, Laccaria laccata, Lactarius tabidus, Paxillus involutus, Boletus badius (=Xerocomus badius) and Boletus chrysenteron (=Xerocomus chrysenteron), were found in all treatments, including the fertilised plots, indicating high ubiquity (Table 3). Six other ECM fungi were present in all the treatments except the fertilised ones: Amanita excelsa var. spissa, L. bicolor, Russula ochroleuca, Russula parazurea, Russula puellaris and Scleroderma citrinum.

In contrast, other ECM fungi showed host preference. For example, Lactarius quietus had 116 times greater chance of being observed in the oak plantation than in the five others (Table 2). Tricholoma ustale, Cantharellus cibarius and Cortinarius delibutus had respectively 97.8, 62.3 and 35.6 times greater chance of being observed in the beech plantation than in the others. Chalciporus piperatus, Gomphidius glutinosus and Craterellus tubaeformis (=Cantharellus tubaeformis) had respectively $36,19.6$ and 16.4 times greater chance of being observed in the Norway spruce plantation than in the other plantations, while Tricholoma fulvum, Cortinarius obtusus and Russula atropurpurea had respectively 73.5, 69.4 and 26.5 times greater chance of being observed in the Douglas-fir plantations. 


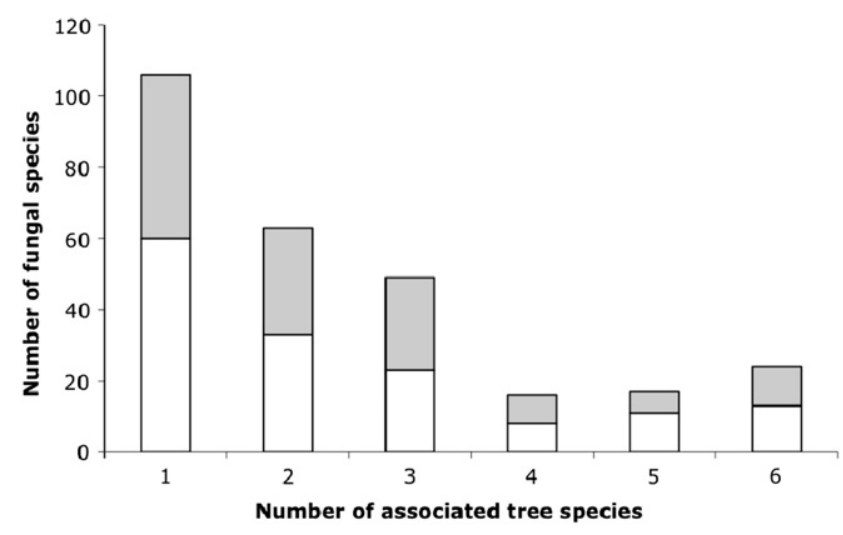

Fig 4 - Number of fungal species associated with different tree species. White bars: ECM fungi; grey bars: saprotrophic fungi.

Among the saprotrophic group, three wood decaying fungi (WDF), Hypholoma fasciculare, Hypholoma lateritium and Mycena galericulata, one litter species (LDF), Rhodocollybia butyracea, one wood decaying fungus living on small twigs on the ground (TSF), Mycena galopus, and one saprotrophic fungus associated with gramineae (GSF), M. epipterygia, were found in all treatments including the fertilised plots (Table 3).

Table 3 - List of the 23 ubiquist fungal species found in the seven tree species treatments (beech, oak, Douglasfir, Corsican pine, Norway spruce, Douglas fir and in the native forest)

\begin{tabular}{|c|c|c|}
\hline Genus & Species & Functional group \\
\hline Amanita & rubescens ${ }^{a}$ & EMF \\
\hline Amanita & excelsa var. spissa & EMF \\
\hline Armillaria & gallica (“Тype E”) & $\mathrm{PF}$ \\
\hline Armillaria & mellea (“Type D”) & PF \\
\hline Collybia & butyracea $^{a}$ & LDF \\
\hline Hypholoma & fasciculare $^{a}$ & WDF \\
\hline Hypholoma & lateritium $^{\mathrm{a}}$ & WDF \\
\hline Laccaria & amethystina $^{\mathrm{a}}$ & EMF \\
\hline Laccaria & bicolor & EMF \\
\hline Laccaria & laccata ${ }^{a}$ & EMF \\
\hline Lactarius & tabidus ${ }^{a}$ & EMF \\
\hline Megacollybia & platyphylla & TSF \\
\hline Mycena & epipterygia ${ }^{a}$ & GSF \\
\hline Mycena & galericulata ${ }^{a}$ & WDF \\
\hline Mycena & galopus $^{\mathrm{a}}$ & TSF \\
\hline Paxillus & involutus $^{\mathrm{a}}$ & EMF \\
\hline Phallus & impudicus & TSF \\
\hline Russula & ochroleuca & EMF \\
\hline Russula & parazurea & EMF \\
\hline Russula & puellaris & EMF \\
\hline Scleroderma & citrinum & EMF \\
\hline Xerocomus & badius $^{a}$ & EMF \\
\hline Xerocomus & chrysenteron $^{\mathrm{a}}$ & EMF \\
\hline
\end{tabular}

a Species present in the 11 treatments including the fertilised plots. EMF, ectomycorrhizal fungi; WDF, wood decaying fungi; LDF, litter decaying fungi living on $\mathrm{F}$ and H layers; TSF, wood decaying fungi living on small twigs on the ground; PF, parasitic fungi; GSF, saprotrophic fungi associated with Gramineae.
Twenty-one saprotrophic fungi (WDF, LDF, TSF and OF) against 25 ECM, were preferentially associated with a particular tree species (Table 2). For example, Bjerkandera adusta had 35.6 times greater chance of being observed in the beech plantation than in the five others, and Postia ptychogaster had 39.3 times greater chance of being observed in the Norway spruce plantation than in the five others (Table 2).

Two parasitic fungi (PF), Armillaria gallica and Armillaria mellea, and one TSF (Megacollybia platyphylla) were present in all treatments except in the fertilised ones.

\section{Succession of ectomycorrhizal fungi}

The succession of ECM fungi with time could be studied only under deciduous species by comparing the native stand and the beech and oak plantations. Eight ectomycorrhizal species, Cortinarius alboviolaceus, Cortinarius bolaris, Lactarius chrysorrheus, Leccinum quercinum, Russula acrifolia, Russula fellea, Tricholoma columbetta and Tricholoma sciodes, rarely appeared in beech plantation and never in oak plantation, but were frequently found in the native stand (Table S5).

By comparing the native stand (NS) with the beech (B) and oak (O) plantations, we also can identify ECM fungi exhibiting a different behaviour to the late-stage species (Table S6). Thirteen ECM fungi, Amanita citrina, Boletus erythropus, C. cibarius, Cortinarius lebretonii, Lactarius camphoratus, L. quietus, L. tabidus, Russula brunneoviolacea, Russula nobilis (=Russula fageticola), Russula fragilis, R. ochroleuca, B. badius (=X. badius) and B. Chrysenteron (=X. chrysenteron), were present both in the native stand and the two deciduous plantations, but were more frequent in the former (Table S6).

Ten other ectomycorrhizal fungi, A. excelsa, var. spissa, A. rubescens, Boletus edulis, C. delibutus, L. amethystina, Lactarius subdulcis, R. parazurea, Russula nigricans, Russula cyanoxantha and T. ustale, exhibited beech (B)/native stand (NS) or oak (O)/ native stand (NS) ratios equal to or greater than 1.0 in at least one deciduous plantation. (Table S6).

The frequency of occurrence of the main edible fungi is given in Table S7.

Finally, we have identified four species that could be classified as primary-stage fungi: L. bicolor, L. laccata, S. citrinum and P. involutus (Table S6). Primary-stage fungi are defined as those that form mycorrhizal associations when trees first establish on sites in natural conditions or in nurseries.

\section{Discussion}

\section{Inclusive effect of the treatments}

This study, brings new knowledge about the effect of host substitution on forest fungal diversity. Nevertheless, it is obvious that by comparing young plantations with an old forest system, we combine two concomitant effects, tree composition and age. Moreover, stumps were mechanically extracted from the planted plots and we know that this trampling disturbance, which was not simulated in the native stands, could affect fruiting patterns (Baar \& Ter Braak 1996).

In this work, the native forest plot seems to show a higher diversity compared to mono-specific plantations, including the 
native tree species plots such as beech and oak plantations, for which the diversity of epigeous ECM and saprotrophic fungi decreases. However, the native forest plot has a greater surface than the planted stands and this may partially explain this higher diversity. This result is different from that of Humphrey et al. 2000, who showed that in northern Britain there were no differences in fungal species richness between conifer plantations (Sitka spruce and Scots pine) and semi-natural woodlands (oak woods and native pinewoods). These different results could be attributed to a variety of factors: differences in ecological conditions, comparison between native pinewoods and pine plantations, comparison between Sitka spruce and native oak woods instead of comparison between a native beech-oak forest and Norway spruce, Douglas-fir, Nordmann fir and Corsican pine. On the other hand, our results are in agreement with those of Amaranthus (1998) in New Zealand and those of Jansen \& de Vries (1988) in Europe.

The effect of soil fertilisation on fungal fruiting was minor in this experiment, contrary to what has been seen by several authors under other conditions (Menge \& Grant 1978; Garbaye \& Le Tacon 1982; Kårén \& Nylund 1997). The small effect of soil fertilisation could be due to the low level of mineral elements applied and their almost complete incorporation in the ecosystem's biomass 30 yr after treatment (Ranger et al. 2004).

\section{Modifications of microclimatic conditions and soil fertility}

Fungal fruiting depends largely on soil moisture (Kropp \& Albee 1996). The differences in ground cover, which determines the quantity of rainfall arriving at the soil surface, could partly explain the differences in fungal richness between the native site and the conifer plantations. Indeed, the humidity of the upper soil zone was always higher in the angiosperm tree treatments than in the coniferous treatments. These factors could contribute to partly explain the high fungal species richness observed in the native stand.

Moreover, soil fertility changes after clear cutting and conversion to plantations (Augusto et al. 2002; Zeller et al. 2007). In the Breuil experiment, potential net nitrification and nitrate concentrations in the $0-15 \mathrm{~cm}$ depth were low in the native stand, in spruce and Nordmann fir plantations, and high in beech, oak and Douglas-fir plantations (Andrianarisoa et al. 2009). The potential net nitrification appeared to be negatively related to fungal species richness confirming previous results reported by Taylor et al. (2000). Trees species develop strategies to control $\mathrm{N}$ cycling and probably nitrification (Chapman et al. 2005). Our results showed a negative feedback between nitrification and fungal diversity, but the mechanisms remain rather speculative. Knops et al. (2002) proposed a tight plant-oriented microbial loop: microbes control the nitrogen cycling, but plants regulate carbon inputs that control microbial activity.

\section{Host preference}

Variations of ectomycorrhizal fungi in host preference are well known (Molina \& Trappe 1982; Newton \& Haigh 1998). This experiment gave new information about the behaviour of ectomycorrhizal fungi in temperate conditions: thirteen ectomycorrhizal species displayed no host preference; A. rubescens, A. excelsa var. spissa, L. amethystina, L. bicolor,
L. laccata, L. tabidus, P. involutus, R. ochroleuca, R. parazurea, R. puellaris, S. citrinum, B. badius (=X. badius) and B. Chrysenteron (=X. chrysenteron). Conversely, several ectomycorrhizal fungi exhibited host preference, for example Cortinarius torvus and Lactarius deterrimus for Norway spruce, and L. subdulcis and R. nobilis (=R. fageticola) for beech. L. quietus was mainly found in oak plantation but sometimes in beech plantation. Thus, this ectomycorrhizal species is not completely dependent on oak as usually implied in the literature.

This experiment also gave new information about the ubiquity and specificity of saprotrophic fungi. Eight saprotrophic fungi, R. butyracea, H. fasciculare, H. lateritium, M. platyphylla, Mycena epipterygia, M. galericulata, M. galopus and Phallus impudicus, were found under all tree species, fertilised or not. They could be considered as completely ubiquitous and indifferent to the composition of the organic residues generated by the different trees. On the other hand, Trametes gibbosa (WDF) was found exclusively under beech but, according to the literature, this white rot fungus could be found on some other hardwoods such as plane tree, lime or poplar (Courtecuisse \& Duhem 1995). This species is temporarily mycoparasitic on Bjerkandera species, and its establishment is probably dependant on the presence of this fungus rather than on tree species (Rayner et al. 1987; Boddy 2000). Two saprotrophic fungi living on dead needles or cones, Mycena rosella and Strobilurus esculentus, were also exclusively found under Norway spruce.

The two PF species, A. gallica and A. mellea, also appeared to be completely ubiquitous.

\section{Succession of ectomycorrhizal fungi}

According to Last et al. (1987), two groups of ectomycorrhizal fungi can be distinguished: late-stage fungi and early-stage fungi. According to our work, C. alboviolaceus, C. bolaris, L. chrysorrheus, L. quercinum, R. acrifolia, R. fellea, T. columbetta and $T$. sciodes, which were present only in the native stand, could be considered as late-stage fungi, while ten others, A. excelsa var. spissa, A. rubescens, B. edulis, C. delibutus, L. amethystina, L. subdulcis, R. parazurea, R. nigricans, R. cyanoxantha and T. ustale, which were present in the planted deciduous plots, could be considered as early-stage fungi. It was thought until now that the early-stage EMF were ubiquitous species (Last et al. 1987), but the present study has revealed that some early-stage EMF, such as T. ustale and C. delibutus, also exhibit host preferences.

We have distinguished two new groups: middle-stage and primary-stage ectomycorrhizal fungi. The middle-stage ectomycorrhizal fungi, which were present both in the native stand and the two deciduous plantations, but were more frequent in the former, comprised A. citrina, B. erythropus, C. cibarius, C. lebretonii, L. camphoratus, L. quietus, L. tabidus, $R$. brunneoviolacea, R. nobilis (=R. fageticola), R. fragilis, R. ochroleuca, $B$. badius ( $=X$. badius) and $B$. chrysenteron ( $=X$. chrysenteron), while the primary-stage ectomycorrhizal fungi comprised L. bicolor, L. laccata, S. citrinum and P. involutus. According to the literature, these four primary-stage fungi are easy to handle, form ectomycorrhizas in 2 months and fruit 1 or 2 yr after the establishment of the symbiosis (Le Tacon et al. 1992).

All of these different types of fungi progressively appear over time and survive during stand aging (Mason et al. 1983; Last et al. 
1987), explaining the fungal richness of the old native forest and the relative paucity of fungal taxa of the planted sites.

Depending on time, the beech and oak seedlings of the planted sites could progressively be associated with all of the naturally occurring ectomycorrhizal fungi, except the latestage fungi, while the coniferous seedlings could form associations only with ubiquitous ECM fungi exhibiting a broad host range. The ECM fungi exhibiting a preference for one or several coniferous species were not present on the site at the time the plantation was established. Over the past $30 \mathrm{yr}$ they have arrived erratically from the neighbouring plantations by airborne spores or carried by animals.

Douglas-fir is an exotic species characterized by the absence of its specific associated fungi in Europe. In the Breuil forest, we only found 49 epigeous EMF under Douglas-fir, whereas Smith et al. (2002), found 86 epigeous ectomycorrhizal species in a young (30-35 yr) Douglas-fir stand in Oregon. Barroetaveña et al. (2007) reported that the ECM fungal community found in native Douglas-fir forests overlap little with those in plantations elsewhere. From the 64 ECM fungi found in plantations all over the world, 28 of them (44\%) have not been recorded in native Douglas-fir forests. By contrast, Nordmann fir and Norway spruce plantations were richer in fungal species. The genus Abies and Picea are native to France, two or three hundred kilometres from the Breuil forest. These relatively short distances could explain the relative richness in fungal species of these two plantations compared to Douglas-fir.

Finally, the loss of fungal diversity in the different plantations compared to the native stand could be attributed to several factors which interact: absence of late-stage fungi, mono-specificity of the plantations, differences in ground cover which results in differences in soil moisture, regularity of the canopy structure, differential effect of host on nitrification, absence of specific fungi for the conifers and particularly for Douglas-fir.

\section{Acknowledgements}

The authors thank the Office National des Forêts and the Parc National du Morvan for funding the Breuil research site. This work was supported by the ANR program "ECCO" and the "Institut Français de la Biodiversité" (IFB). We also thank all the students and colleagues who participated in the numerous sampling operations and particularly Dominique Gelhaye and Pascal Bonnaud. We also greatly thank Francis Martin, Anne Pringle and the two anonymous referees of the journal for their help in reviewing the manuscript.

\section{Supplementary data}

The supplementary data associated with this article can be found in the on-line version at doi:10.1016/j.funeco.2010.07.003.

\section{R E F E R E N C E S}

Andrianarisoa KS, Zeller B, Dupouey JL, Dambrine E, 2009. Comparing indicators of $\mathrm{N}$ status of 50 beech stands (Fagus sylvatica L.) in northeastern France. Forest Ecology and Management 257: 2241-2253.

Amaranthus MP, 1998. The Importance and Conservation of Ectomycorrhizal Fungal Diversity in Forest Ecosystems: lessons from Europe and the Pacific Northwest. General Technical Report PNW-GTR-431. Department of Agriculture, Forest Service, Pacific North West Research Station.

Augusto L, Ranger J, Binkley D, Rothe A, 2002. Impact of several common tree species of European temperate forests on soil fertility. Annals of Forest Science 59: 233-253.

Baar J, Ter Braak CJF, 1996. Ectomycorrhizal sporocarp occurrence as affected by manipulation of litter and humus layers in Scots pine stands of different age. Applied Soil Ecology 4: 61-73.

Barroetaveña C, Cázares E, Rajchenberg M, 2007. Ectomycorrhizal fungi associated with ponderosa pine and Douglas-fir: a comparison of species richness in native western North American forests and Patagonian plantations from Argentina. Mycorrhiza 17: 355-373.

Boddy L, 2000. Interspecific combative interactions between wood-decaying basidiomycetes. FEMS Microbiology Ecology 31: 185-194.

Buée M, Vairelles D, Garbaye J, 2005. Year-round monitoring of diversity and potential metabolic activity of the ectomycorrhizal community in a beech (Fagus sylvatica) forest subjected to two thinning regimes. Mycorrhiza 15: 235-245.

Buée M, Courty PE, Mignot D, Garbaye J, 2007. Soil niche effect on species diversity and catabolic activities in an ectomycorrhizal fungal community. Soil Biology and Biochemistry 39: 1947-1955.

Chapman SK, Langley JA, Hart SC, Koch GW, 2005. Plants actively control nitrogen: uncorking the microbial bottleneck. New Phytologist 169: 27-34.

Courtecuisse R, Duhem B, 1995. Mushrooms and Toadstools of Britain and Europe. Harper Collins, London.

Courtecuisse R, 2008. Référentiel National. www.mycofrance.com/ outils.html (accessed 29.09.09.).

Durall DM, Todd DM, Trappe JM, 1994. Decomposition of 14Clabelled substrates by ectomycorrhizal fungi in association with Douglas fir. New Phytologist 127: 725-729.

El-Badaoui K, Botton B, 1989. Production and characterization of extracellular protéases in ectomycorrhizal fungi. Annals of Forest Science 46S: 728-730.

Erland S, Taylor AFS, 2002. Diversity of ecto-mycorrhizal fungal communities in relation to the abiotic environment. In: van der Heijden, MGA, Sanders, I (eds), Mycorrhizal Ecology. Ecological Studies, vol. 157. Springer-Verlag, Berlin/Heidelberg, pp. 163-200.

Ferris R, Peace AJ, Newton AC, 2000. Macrofungal communities of lowland Scots pine (Pinus sylvestris L.) and Norway spruce (Picea abies (L) Karsten) plantations in England: relationships with site factors and stand structure. Forest Ecology and Management 131: 255-267.

Garbaye J, Le Tacon F, 1982. Influence of mineral fertilization and thinning intensity on the fruit body production of epigeous fungi in an artificial spruce stand (Picea excelsa Link.) in north-eastern France. Acta Oecologica, Oecologia Plantarum 3: 153-160.

Genney DR, Anderson IC, Alexander IJ, 2005. Fine-scale distribution of pine extomycorrhizas and their extrametrical mycelium. New Phytologist 170: 381-390.

Humphrey JW, Newton AC, Peace AJ, Holden E, 2000. The importance of conifer plantations in northern Britain as a habitat for native fungi. Biological Conservation 96: 242-252.

Ishida A, Nara K, Hogetsu T, 2007. Host effects on ectomycorrhizal fungal communities: insight from eight host species in mixed conifer-broad-leaf forests. New Phytologist 174: 430-440.

Jansen AE, de Vries FW, 1988. Qualitative and quantitative research on the relation between ectomycorrhiza of 
Pseudotsuga menziesii, vitality of the host and acid rain. Report 25-02. Dutch Priority Programme on acidification. LU, Wageningen/RIVM, Bilthoven 73 pp.

Kårén O, Nylund J-E, 1997. Effects of ammonium sulphate on the community structure and biomass of ectomycorrhizal fungi in a Norway spruce stand in southwestern Sweden. Canadian Journal of Botany 75: 1628-1642.

Knops JMH, Bradley KL, Wedin DA, 2002. Mechanisms of plant species impacts on ecosystem nitrogen cycling. Ecology Letters 5: $454-466$

Koide RT, Shumway DL, Xu B, Sharda JN, 2007. On temporal partitioning of a community of ectomycorrhizal fungi. New Phytologist 174: 420-429.

Kropp BR, Albee S, 1996. The effects of silvicultural treatments on occurrence of mycorrhizal sporocarps in a Pinus contorta forest: a preliminary study. Biological Conservation 78: 313-318.

Küffer N, Senn-Irlet B, 2005. Influence of forest management on the species richness and composition of wood-inhabiting basidiomycetes in Swiss forests. Biodiversity and Conservation 14: 2419-2435.

Laganà A, Loppi S, De Dominicis V, 1999. Relationship between environmental factors and the proportions of fungal trophic groups in forest ecosystems of the central Mediterranean area. Forest Ecology and Management 124: 145-151.

Last FT, Dighton J, Mason PA, 1987. Successions of sheathing fungi. Trends in Ecology and Evolution 2: 157-160.

Le Tacon F, Alvarez IF, Bouchard D, Henrion B, Jackson RM, Luff S, Parlade JI, Pera J, Stenstrom E, Villeneuve N, Walker C, 1992. Variations in field response of forest trees to nursery ectomycorrhizal inoculation in Europe. In: Read, DJ, Lewis, DH, Fitter, A, Alexander, I (eds), Mycorrhizas in Ecosystems. CAB International UK, Wallingford, Oxon, pp. 119-134.

Lindahl BD, Ihrmark K, Boberg J, Trumbore SE, Högberg P, Stenlid J, Finlay RD, 2007. Spatial separation of litter decomposition and mycorrhizal nitrogen uptake in a boreal forest. New Phytologist 173: 611-620.

Lindhe A, Asenblad N, Toressson H-G, 2004. Cut logs and high stumps of spruce, birch, aspen and oak - nine years of saproxylic fungi succession. Biological Conservation 119: 443-454.

Mason PA, Wilson J, Last FT, Walker C, 1983. The concept of succession in relation to the spread of sheathing mycorrhizal fungi on inoculated tree seedlings growing in unsterile soils. Plant and Soil 71: 247-256.

Menge JA, Grant L, 1978. Effect of fertilization on production of epigeous basidiocarps by mycorrhizal fungi in loblolly pine plantations. Canadian Journal of Botany 56: 2357-2362.

Molina R, Trappe JM, 1982. Patterns of ectomycorrhizal host specificity and potential among Pacific Northwest conifers and fungi. Forest Science 28: 423-458.

Newton AC, Haigh JM, 1998. Diversity of ectomycorrhizal fungi in Britain: a test of the species-area relationship and the role of host specificity. New Phytologist 138: 619-627.

Nordén B, Paltto H, 2001. Wood-decay fungi in hazel wood: species richness correlated to stand age and dead wood features. Biological Conservation 101: 1-8.

Nordén B, Ryberg M, Götmark F, Olausson B, 2004. Relative importance of coarse and fine woody debris for the diversity of wood-inhabiting fungi in temperate broadleaf forest. Biological Conservation 117: 1-10.
Peter M, Ayer F, Egli S, 2001. Nitrogen addition in a Norway spruce stand altered macromycetes sporocarp production and belowground ectomycorrhizal species composition. New Phytologist 149: 311-325.

Ranger J, Andreux F, Bienaimé S, Berthelin J, Bonnaud P, Boudot JP, Bréchet C, Buee M, Calmet JP, Chaussod R, Gelhaye D, Gelhaye L, Gérard F, Jaffrain J, Lejon D, Le Tacon F, Lévêque J, Maurice JP, Merlet D, Moukoumi J, Munier-Lamy C, Nourrisson G, Pollier B, Ranjard L, Simonsson M, Turpault MP, Vairelles D, Zeller B, 2004. Effets des substitutions d'essence sur le fonctionnement organo-minéral de l'écosystème forestier, sur les communautés microbiennes et sur la diversité des communautés fongiques mycorhiziennes et saprophytes (cas du dispositif de Breuil - Morvan), Rapport final contrat INRAGIP Ecofor 2001-24, No. INRA 1502A, INRA Biogéochimie des Ecosystèmes forestiers, 54280 Champenoux.

Rayner ADM, Boddy L, Dowson CG, 1987. Temporary parasitism of Coriolus spp. by Lenzites betulina: a strategy for domain capture in wood decay fungi. FEMS Microbiology Ecology 45: 53-58.

Richard F, Moreau P-A, Selosse M-A, Gardes M, 2004. Diversity and fruiting patterns of ectomycorrhizal and saprobic fungi in an old-growth Mediterranean forest dominated by Quercus ilex. L. Canadian Journal of Botany 82: 1711-1729.

Schmit JP, Mueller GM, 2007. An estimate of the lower limit of global fungal diversity. Biodiversity and Conservation 16: 99-111.

Smith JE, Molina R, Huso MMP, Luoma DL, Mckay D, Castellano MA, Lebel T, Valachovic Y, 2002. Species richness, abundance, and composition of hypogeous and epigeous ectomycorrhizal fungal sporocarps in young, rotation-age, and old-growth stands of Douglas-fir (Pseudotsuga menziesii) in the Cascade Range of Oregon, USA. Canadian Journal of Botany 80: 186-204.

Takumasu S, Aoki T, Oberwinkler F, 1994. Fungal succession on pine needles in Germany. Mycoscience 35: 29-37.

Taylor AFS, Martin F, Read DJ, 2000. Fungal diversity in ectomycorrhizal communities of Norway spruce (Picea abies (L.) Karst.) and beech (Fagus sylvatica L.) along a north-south transect in Europe. In: Schulze, E-D (ed), Carbon and Nitrogen Cycling in European Forest Ecosystems. Ecological Studies, vol. 142. Springer Verlag, Heidelberg, pp. 343-365.

Tedersoo L, Kõljalg U, Hallenberg N, Larsson KH, 2003. Fine scale distribution of ectomycorrhizal fungi and roots across substrate layers including coarse woody debris in a mixed forest. New Phytologist 159: 153-165.

Tedersoo L, Jairus T, Horton BM, Abarenkov K, Suvi I, Saar I, Koljalg U, 2008a. Strong host preference of ectomycorrhizal fungi in a Tasmania wet sclerophyll forest as revealed by DNA barcoding and taxon-specific primers. New Phytologist 180: 479-490.

Tedersoo L, Suvi T, Jairus T, Koljalg U, 2008b. Forest microsite effects on community composition of ectomycorrhizal fungi on seedlings of Picea abies and Betula pendula. Environmental Microbiology 10: 1189-1201.

Zeller B, Recous S, Kunze M, Moukoumi J, Colin-Belgrand M, Bienaimé S, Ranger J, Dambrine E, 2007. Influence of tree species on gross and net $\mathrm{N}$ transformations in forest soils. Annals of Forest Science 64: 151-158.

Zhou D, Hyde K, 2001. Host-specificity, host-exclusivity, and hostrecurrence in saprobic fungi. Mycological Research 105: 1449-1457. 